VOLUME 18 | ISSUE 3 | JULY 2015 | ISSN 1366-7289

\title{
BILINGUALISM: LANGUAGE AND COGNITION
}

EDITORS JUBIN ABUTALEBI \& HARALD CLAHSEN

\section{TOSPROGETHED.}

BILINGVISMUS ثنائية

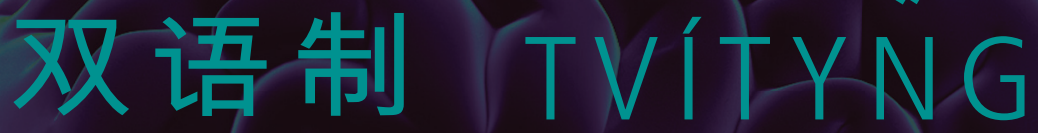

TWEETALIGHEID DWYIEITHRWYDD

BILINGVIZMUS BILINGÜIS MO

TOSPRÁKLIGHET 2 개 국 어 상용

バイリカガリズム(二言語併用 )

สิองภา ใด

BILINGUISMO 


\section{Bilingualism: Language and Cognition}

$B L C$ is an international peer-reviewed journal focusing on bilingualism from a linguistic, psycholinguistic, and neuroscientific perspective. The aims of the journal are to promote research on the bilingual and multilingual person and to encourage debate in the field. Areas covered include: bilingual language competence, bilingual language processing, bilingual language acquisition in children and

adults, bimodal bilingualism, neurolinguistics of bilingualism in normal and brain-damaged individuals, computational modelling of bilingual language competence and performance, and the study of cognitive functions in bilinguals. $B L C$ carries articles and research notes on all aspects of the bilingual person, and is published four times a year.

\section{EDITORS IN CHIEF}

Jubin Abutalebi San Raffaele University

Harald Clahsen University of Potsdam

\section{ASSOCIATE EDITORS}

Debra Jared University of Western Ontario Robert DeKeyser University of Maryland

Ludovica Serratrice University of Manchester Natasha Tokowicz University of Pittsburgh

\section{FOUNDING EDITORS}

\section{EDITORIAL BOARD}

Ellen Bialystok York University

Ellen Broselow Stony Brook University

Marc Brysbaert Ghent University

Susanne E. Carroll University of Calgary

Albert Costa University of Barcelona

Ruth de Diego Balaguer University of Barcelona

Annette M. B. de Groot University of Amsterdam

Pasquale Anthony Della Rosa San Raffaele University

Ton Dijkstra University of Nijmegen

Guosheng Ding Beijing Normal University

Yanping Dong Guangdong University of Foreign Studies

Karen Emmorey San Diego State University

Claudia Felser University of Potsdam

Julia Festman University of Potsdam

Cristina Flores University of Minho

Cheryl Frenck-Mestre University of Provence

Fred Genesee McGill University

Narly Golestani University of Geneva

Tamar Gollan University of California at San Diego

Kira Gor University of Maryland

David W. Green University College London

Aafke Hulk University of Amsterdam

Kenneth Hyltenstam Stockholm University

Tania Ionin University of Illinois
Kathryn Kohnert University of Minnesota

Tanja Kupisch University of Hamburg

Elizabeth Lanza University of Oslo

Ping Li Pennsylvania State University

Conxita Lleó University of Hamburg

Gigi Luk Harvard University

Elena Nicoladis University of Alberta

Johanne Paradis University of Alberta

Teresa Parodi University of Cambridge

Aneta Pavlenko Temple University

Ana T. Pérez-Leroux University of Toronto

Monika Rothweiler University of Bremen

Núria Sebastián-Gallés University of Barcelona

Carmen Silva-Corvalán University of Southern California

Hua Shu Beijing Normal University

Jeanine Treffers-Daller University of Reading

Annie Tremblay University of Kansas

Ianthi M. Tsimpli University of Reading

Roger Van Gompel Dundee University

Yue Wang Simon Fraser University

Brendan Weekes University of Hong Kong

Virginia Yip Chinese University of Hong Kong

Xiaowei Zhao Emmanuel College, Boston

\section{EDITORIAL ASSISTANTS}

